\title{
PENGARUH PENDEKATAN HIGHER ORDER THINKING SKILL (HOTS) TERHADAP KETERAMPILAN MEMBACA SISWA KELAS X SMK NEGERI 3 KOTA SUKABUMI
}

\author{
Nyova Fazriani, Deden Ahmad Supendi, Hera Wahdah Humaira \\ Universitas Muhammadiyah Sukabumi \\ fazrianinyova@gmail.com
}

\begin{abstract}
ABSTRAK
Penelitian ini bertujuan untuk mengetahui bagaimana keterampilan membaca siswa setelah menggunakan pendekatan Higher Order Thinking Skill (HOTS). Jenis penelitian ini adalah kuantitatif dan desain penelitian yang digunakan pre experimental design dengan model the one group pretest-posttest. Populasi penelitian kelas X SMK Negeri 3 Kota Sukabumi dengan sampel penelitian yang digunakan yaitu purposive sampling dan kelas yang dijadikan sampel penelitian yaitu $\mathrm{X}$ Jasa Boga I. Instrumen dalam penelitian ini menggunakan soal HOTS bahasa Indonesia pilihan ganda sebanyak 20 butir beserta alasan. Berdasarkan uji prasyarat normalitas dan homogenitas bahwa data hasil penelitian berdistribusi tidak normal dan kedua kelas memiliki varians yang homogen. Diketahui analisis data distribusi prates diperoleh hasil Mean 56.17 sedangkan pascates setelah diberikan stimulus atau perlakuan dengan pendekatan HOTS diperoleh hasil Mean 72.06, maka terdapat peningkatan nillai hasil belajar pascates setelah dilalukan stimulus dengan menerapkan pendekatan HOTS pada pembelajaran. Terdapat perbedaan yang signifikan terhadap hasil belajar siswa, dibuktikan dalam Uji-t diperoleh $t_{\text {hitung }}>t_{\text {tabel }}$ (13.69 > 2.042) dan uji Wilcoxon Sign rank yang menghasilkan nilai (asym.sig. (2tailed)) adalah $0.000<0.05$ maka hasil hipotesis $\mathrm{H}_{0}$ ditolak dan $\mathrm{H}_{1}$ diterima. Hal ini dapat disimpulkan bahwa terdapat pengaruh hasil belajar pada kemampuan berpikir siswa pada saat pembelajaran dengan menggunakan pendekatan Higher Order Thinking Skill (HOTS) terhadap keterampilan membaca siswa.
\end{abstract}

\section{Kata kunci: Pendekatan Higher Order Thinking Skill (HOTS), Keterampilan Membaca}

\begin{abstract}
This study aims to find out how students read skills after using the Higher Order Thinking Skill (HOTS) approach. This type of research is quantitative and research design used is pre-experimental design with the one group pretest-posttest model. The research population in class X of State Vocational High School 3 in Sukabumi City with the research sample used was purposive sampling and the class that was used as the study sample, namely X Jasa Boga I. The instrument in this study used HOTS Indonesian multiple choice as many as 20 items along with reasons. Based on the normality and homogeneity prerequisite test that the research dat is abnormally distributed and both classes have homogeneous variances. It is known that the distribution data analysis pretest showed that the result of mean 56.17 while the posttest after being given a stimulus or treatment with the HOTS approach
\end{abstract}


showed mean 72.06, then there was a significant increase in posttest learning outcomes after stimulus by applying the HOTS approach to learning. There are significant differences in student learning outcomes, as evidenced in the t-test obtained by $t_{\text {count }}>t_{\text {tabel }}(13.69>2.042)$ and the Wilcoxon Sign Rank test which produces a value (asym.sig. (2-tailed)) is $0.000<0.05$ then the hypothesis $\mathrm{H}_{0}$ rejected $\mathrm{H}_{1}$ accepted. It can be cocluded that there is an effect of learning outcomes on students thinking skills during learning using the Higher Order Thinking Skill (HOTS) approach to students reading skills.

Keywords: Approach to Higher Order Thinking Skill (HOTS), Reading Skills

\section{PENDAHULUAN}

Berpikir dapat dilakukan sebagai kegiatan mental dalam membantu merumuskan atau menyusun sebuah gagasan yang akan disampaikan. Maka dari itu berpikir sesuatu hal yang tidak lepas dari diri manusia. Macam-macam berpikir menurut De Porter dan Hernacki (dalam Maulana, 2018:5-6) mengklasifikasikan bentuk pemikiran menjadi sebagian proses, yakni secara vertikal, lateral, kritis, analitis, strategis, dan kreatif.

Kemampuan berpikir yang dimiliki manusia terdapat perbedaan di antaranya menurut Presseien (dalam Maulana, 2018:6) dibedakan kemampuan berpikir menjadi dua aspek, ialah kemampuan berpikir dasar dan kemampuan berpikir tinggi. Adapun kemampuan berpikir dasar adalah deskripsi dari cara berpikir secara logis dan mendasar. Kemudian berikut yang tergolong berpikir tingkat tinggi yakni kemampuan penyelesaian masalah (problem solving), pengambilan keputuan (decision making), kreatif (creative), dan kritis (critical).

Taksonomi Bloom merevisi tingkat kognitif yang di antaranya kegiatan berpikir dibagi menjadi dua tingkatan yang disebut kemampuan berpikir tingkat rendah (Lower Order Thinking Skill) dan kemampuan berpikir tingkat tinggi (Higher Order Thinking Skill). Hal yang dibutuhkan abad ke XXI ini adalah kemampuan berpikir tingkat tinggi atau (Higher Order Thinking Skill) yang menekankan pada pemikiran lebih tinggi terhadap kemampuan memecahkan masalah, berpikir kritis, kretaif, dan mengambil keputusan. Hal tersebut untuk menggunakan pikiran dalam menghadapi tantangan baru dikemudian hari. 
Tujuan dari penelitian adalah untuk mengetahui keterampilan membaca siswa setelah diterapkan pembelajaran menggunakan pendekatan Higher Order Thinking Skill (HOTS). Diberikan satu perlakuan dengan satu kelas eksperimen dan melihat hasil perbandingan melalui tahap prates dan pascates.

Secara garis besar yang melandasi kemampuan berpikir tingkat tinggi yaitu kecakapan dalam berpikir menyambung pada daya nalar sukar. Landasan HOTS ini memberatkan pada masalah seperti mengetahuinya bagaimana melainkan mengetahui apa. Akibatnya akan menekankan seseorang pada kemampuan berpikir analisis serta upaya pendidik dalam melatih kemampuan berpikir tingkat tinggi siswa dengan berbagai cara daripada hanya mengandalkan ingatan yang mudah dan pengajaran secara diktator.

Kemampuan berpikir tingkat tinggi memiliki posisi yang sangat penting dalam pembelajaran, mengembangkan unsur-unsur dalam pembelajaran yang tidak mengacu pada ingatan atau hafalan peserta didik sekolah harus mampu untuk pencapaian nilai atau hasil yang maksimal dan tinggi. Untuk pelaksanaan dalam mengembangkan kemampuan berpikir tingkat tinggi tugas sekolah perlu melakukan tahapan-tahapan yang dimulai perencanaan, Rencana Pelaksanaan Pembelajaran (RPP) dimulai dari kegiatan awal hingga evaluasi, kegiatan belajar mengajar dan Penilaian Pelaksanaan Kelas (PPK).

Cara mengetahui siswa memiliki kemampuan berpikir tingkat tinggi dapat melakukan pembelajaran menggunakan pendekatan HOTS dan melakukan tahap evaluasi berupa asesmen atau penilaian. Pendekatan HOTS diterapkan pada kegiatan pembelajaran di kelas dengan menerapkan model pembelajaran problem solving atau problem based learning dan 4C (critical thinking, creativity, collaborative, communication) serta asesmen berupa tes yang dapat mengukur kemampuan berpikir siswa dalam mengerjakan soal dan memiliki pengaruh dalam penentuan keterampilan berpikir yang dimiliki siswa tersebut.

Penelitian ini berfokus pada pendekatan HOTS terhadap keterampilan membaca siswa. Karena dengan membaca dapat melatih kemampuan berpikir siswa semakin bertambah tinggi. Penerapan literasi yang terdapat di sekolah membaca menjadi pilihan nomor satu untuk terus dikembangkan pada siswa di sekolah. Oleh karena itu, perlu menjadi pembiasaan bagi siswa untuk membaca, karena di kurikulum 2013 
siswa diberi acuan kepada aspek literatur siswa. Dalman (2013:5) mengungkapkan keterampilan membaca ialah sebuah kemampuan dengan kegiatan yang berusaha untuk menggali informasi yang terdapat pada tulisan. Pemahaman dalam membaca dapat di uji dengan pertanyaan yang lebih ada dalam isi buku atau ulasan mengenai apa yang telah didapat dari sebuah bacaan. Kemudian Sadhono dan Slamet (dalam Purnamasari 2014:12), masih mengenai keterampilan membaca yang merupakan kemampuan berorientasi dan memahami informasi dalam bentuk tulisan dengan berbagai macam bentuk dan tanda.

Ukuran dalam memahami suatu bacaan peserta didik tidak lepas dari sebuah kecepatan waktu membaca. Setiap ukuran yang kaitannya kemampuan membaca ini tentu meliputi kecepatan dan memahami isi dari bacaan tersebut. Tampubolon (dalam Meliyawati, 2016:61) mengemukakan mengenai kemampuan membaca yaitu kecepatan dalam membaca dan pemahaman isi bacaan dengan menyeluruh. Sedangkan menurut Mulyati (dalam Meliyawati, 2016:61) kemampuan membaca merupakan sanggup tidaknya melihat disertai langsung memahami isi yang tertulis kemudian dilakukan secara komprehensif ataupun dalam hati.

Kemampuan siswa di Indonesia masih mengandalkan tingkatan kognitif yang rendah, yakni mengingat atau hafalan. Berkaitan dengan kemampuan berpikir tingkat tinggi, permasalahan kemampuan berpikir yang dimiliki siswa dalam membaca masih tingkat rendah dan belum mencapai tingkat tinggi. Tidak mampunya menyelesaikan masalah dan gagasan dalam pertanyaan, oleh karena itu bahwa keterampilan membaca perlu diperhatikan lebih karena dari kemampuan berpikir tingkat tinggi yang terus dilatih siswa dapat mengeksplor pikirannya, melatih menganalisis, dan terbiasa bertemu dengan teks yang panjang.

Berdasarkan yang telah dipaparkan sebelumnya, upaya untuk mengatasi hal ini salah satunya dengan penerapan pendekatan HOTS dalam pembelajaran bahasa Indonesia yang dikembangkan dari pendekatan saintifik. Terdapat sebuah pendekatan pembelajaran yang dapat digunakan untuk mengubah kebiasaan berpikir siswa yakni HOTS. Heong, dkk, (2011) mengemukakan bahwa keterampilan berpikir tingkat tinggi adalah salah satu komponen dari kemampuan berpikir kreatif dan berpikir kritis. Selanjutnya Gunawan dalam Julia, dkk, (2018:369) mengutarakan bahwa berpikir tingkat tinggi merupakan cara berpikir yang melibatkan peserta didik untuk 
menipu daya informasi dan konsep dengan khusus dengan memberikan arti dan keterlibatan yang baru.

Sementara Hanifah dan Julia (2014:372) bagian dari kemampuan berpikir yang mencakup dalam berpikir tingkat tinggi di antaranya, kemampuan berpikir kritis, kreatif, dan analitis. Kemudian masih dengan pendapat yang sama Zaini dalam Julia, dkk, (2018:370) bahwa keterampialn berpikir kritis dan kreatif merupakan perpaduan yang didasari oleh berpikir tingkat tinggi. Artinya, HOTS yang digunakan peneliti diharapkan siswa mampu berpikir secara kritis, kreatif, dan menyelesaikan masalahnya sendiri tidak tergantung pada guru. Hal ini guru hanya memiliki peran sebagai mediator dalam kelas, selebihnya siswa yang menemukan hingga memecahkan masalahnya. Dengan demikian, diharapkan pendekatan HOTS ini dapat diterapkan dalam setiap pembelajaran dengan baik untuk melatih kemampuan berpikir siswa agar dapat menemukan pengalaman belajar secara alamiah.

Penelitian yang dilakukan peneliti terletak pada dua titik yakni lokus dan fokus. Lokus, dalam penelitian ini dilakukan di sekolah SMK Negeri 3 Kota Sukabumi dan fokus dalam penelitian ini pada pengaruh pendekatan kemampuan berpikir tingkat tinggi terhadap keterampilan membaca siswa kelas $\mathrm{X}$ khususnya dalam hasil asesmen soal HOTS bahasa Indonesia. Peneliti sangat tertarik pada penelitian ini karena layak untuk diketahui gambaran penggunaan pendekatan pembelajaran Higher Order Thinking Skill (HOTS) siswa di sekolah tersebut, khususnya pada mata pelajaran bahasa Indonesia. Sehingga dapat melihat pengaruh terhadap proses pembelajaran tersebut dan pengaruh terhadap asesmen soal HOTS yang diujikan. Jika fokus terhadap keterampilan membaca hal ini mengukur sejauh mana siswa dapat beralih kebiasaan menghafalnya menjadi menganalisis sebuah teks atau bacaan. Penerapan pengaruh ini tidak hanya sekadar untuk mengetahui melainkan sebagai pembiasaan terhadap siswa khususnya di mata pelajaran bahasa Indonesia.

\section{METODE PENELITIAN}

Jenis penelitian ini adalah kuantitatif yang terdapat dua variable, yaitu variabel bebas dan variable terikat dengan menggunakan satu kelas eksperimen. Maka desain penelitian yang digunakan adalah pre experimental design dengan model the one group pretest-posttest. Populasi penelitian satu kelas dari kelas X SMK Negeri 3 Kota 
Sukabumi. Pengumpulan data dalam penelitian menggunakan dua instrumen. Instrumen yang pertama soal HOTS bahasa Indonesia berbentuk pilihan ganda guna memperoleh data mengenai kemampuan berpikir siswa terhadap keterampilan membaca dengan melihat hasil prates sebelum diberi stimulus dan pascates sesudah diberi stimulus menggunakan pendekatan HOTS. Instrumen kedua menggunakan lembar observasi guru dan siswa. Soal HOTS bahasa Indonesia ini digunakan untuk mendapatkan skor pada setiap indikator kemampuan berpikir yang dikonversikan dalam bentuk nilai, kemudian untuk melihat peningkatan nilai siswa yakni memakai uji $\operatorname{Gain}(d)$.

Penelitian ini dilakukan di SMKN 3 Kota Sukabumi pada semester genap tahun ajaran 2018/2019. Populasi yang diambil dalam penelitian adalah kelas X SMKN 3 Kota Sukabumi dan sampel menggunakan purposive sampling, mengambil satu kelas sebagai kelas eksperimen yakni X Jasa Boga I. Variabel dalam penelitian ini terdiri dari dua variabel yakni (1) Variabel bebas, pendekatan Higher Order Thinking Skill (HOTS), sedangkan variabel terikat, keterampilan membaca siswa. Penelitian dilaksanakan selama tiga kali pertemuan. Pertemuan pertama kegiatan prates yang dilaksanakan dikelas X Jasa Boga I. Pertemuan kedua yaitu pemberian stimulus atau perlakuan dengan menggunakan pendekatan HOTS. Terakhir pertemuan ketiga tahap pascates. Setiap pertemuan dilakukan selama 4 x 45 menit. Waktu yang dipergunakan menyesuaikan dengan jam pelajaran bahasa Indonesia di kelas X SMKN 3 Kota Sukabumi.

Teknik analisis data yakni analisis statistik inferensial yang digunakan untuk menguji uji-t. Kemudian melakukan uji normalitas dan homogenitas. Pengujian normalitas dilihat dari Kolmogorov-Smirnov untuk mengetahui data yang di tes dalam distribusi normal atau tidak. Kriteria yang digunakan adalah data dari hasil belajar jika pupulasi yang berdistribusi normal memiliki nilai $\mathrm{p}$-value $>\alpha=0.05$. Sementara uji homogenitas dilakukan untuk mengetahui kedua data dari prates dan pascates dikatakan memiliki varians homogen atau tidak. Pengujian dapat dilihat dari Test of Homogenity of Variance dengan data yang diperoleh hasil belajar dikatakan homogen jika p-value $>\alpha=0.05$.

Pengujian ini dilakukan untuk menjawab hipotesis penelitian yang diajukan. Dikarenakan sebelumnya peneliti telah melakukan tahap uji normalitas dan hasilnya 
dinyatakan data tersebut tidak normal maka pengujian yang dilakukan uji Wilcoxon sign rank. Pengujian ini dilakukan dengan menggunakan aplikasi Spss versi 0.7. Kemudian tahapan penelitian yang dilakukan di antaranya: (1) Pra penelitian, (2) Pasca penelitian, (3) Penyelesaian.

\section{PEMBAHASAN}

\section{Hasil Penelitian}

Berdasarkan hasil penelitian, untuk mengetahui pengaruh pendekatan HOTS terhadap keterampilan membaca siswa, adapun hasil data yang diambil dari prates dan pascates masing- masing berjumlah 20 soal HOTS bahasa Indonesia pilihan ganda beserta alasan. Data hasil tes ini diperoleh dari siswa yang telah melakukan prates sebelum diberi stimulus dan pascates setelah diberi stimulus menggunakan pendekatan HOTS. Langkah awal yang dilakukan peneliti melakukan validitas instrument soal prates dan pascates. Validitas yang digunakan peneliti yakni validitas isi dan konstruk sebelum digunakan dan dilanjutkan dengan pemberian stimulus penerapan pendekatan HOTS terhadap keterampilan membaca siswa.

Kegiatan awal tes dilakukan tanpa pembelajaran di kelas, siswa diberikan soal prates tanpa persiapan apapun. Prates ini bertujuan untuk mengetahui kemampuan berpikir siswa kelas X Jasa Boga I SMKN 3 Kota Sukabumi. Setelah pembelajaran dilakukan siswa kemudian melakukan pascates dengan tujuan untuk mengetahui kemampuan berpikir siswa setelah diberikan stimulus dengan mengggunakan pendekatan Higher Order Thinking Skill (HOTS). Kegiatan penelitian pascates dilakukan sama dengan prates yaitu pemberian soal HOTS Bahasa Indonesia. Perhitungan Gain (d) bertujuan untuk mengetahui indeks peningkatan kemampuan berpikir siswa terhadap keterampilan membaca sebelum diberikan stimulus dan setelah diberikan stimulus. Berikut di bawah ini rekapitulasi rata-rata nilai prates, pascates, dan Gain (d).

Tabel 1.1

Rekapitulasi Nilai Tes

\begin{tabular}{cccc}
\hline \multirow{2}{*}{ Kelas } & Rata-rata nilai \\
\cline { 2 - 4 } & Prates & Pascates & $\begin{array}{c}\text { Gain } \\
(\boldsymbol{d})\end{array}$ \\
\hline X Jasa Boga 1 & 56.17 & 72.06 & 540 \\
\hline
\end{tabular}


Berdasarkan tabel 1 dapat diketahui nilai rata-rata prates memiliki perbedaan dengan pascates, nilai rata-rata yang diperoleh prates adalah 56.17 sedangkan nilai rata-rata pascates adalah 72.06. Dari kedua perbandingan tersebut menyatakan kemampuan siswa sudah terlihat berbeda, saat dilakukan pascates lebih tinggi nilai rata-rata yang diperoleh. Perbadingan nilai rata-rata prates dan pascates setelah diberikan stimulus dengan penerapan pendekatan HOTS mengalami peningkatan. Berikut grafik perbandingan nilai rata-rata prates dan pascates.

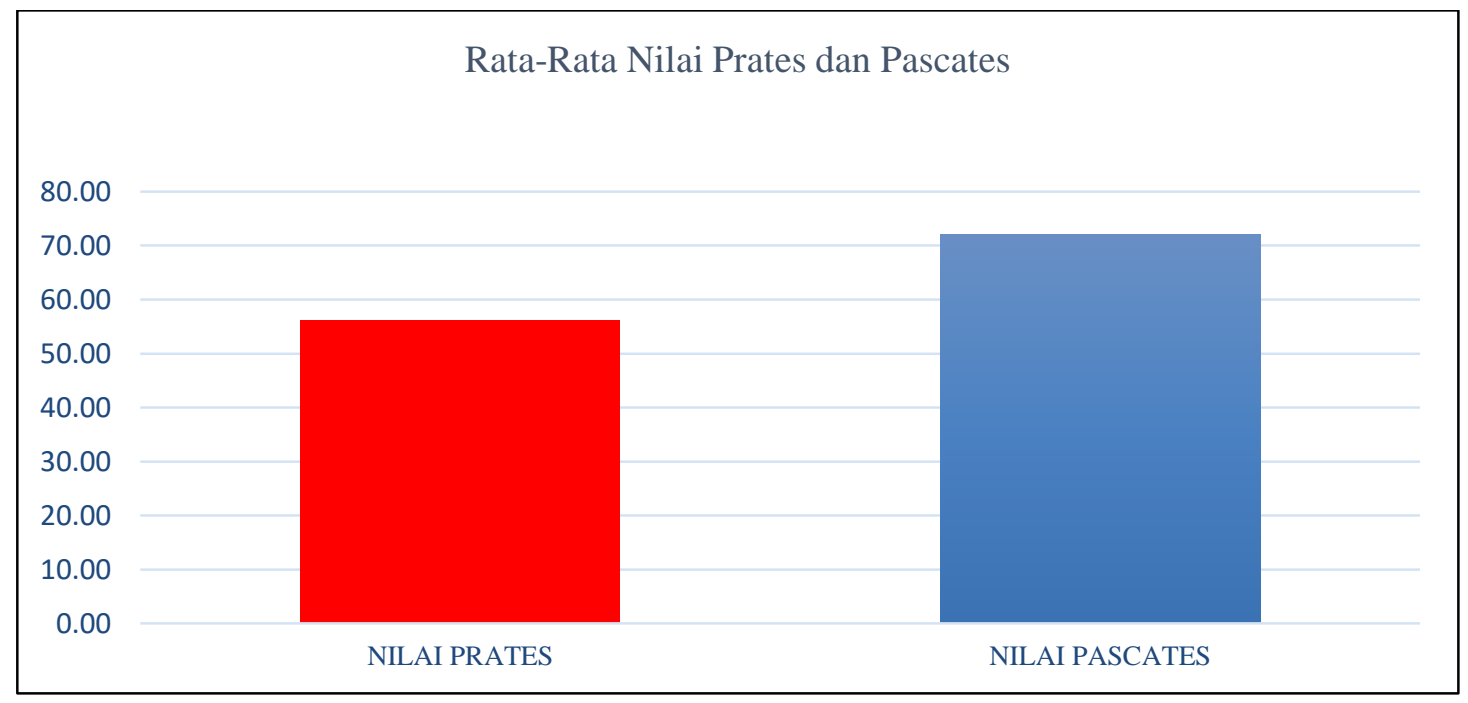

Gambar 1

Grafik Perbandingan Rata-Rata Nilai Prates dan Pascates

Setelah dilakukan perhitungan hasil nilai prates dan pascates, untuk membuktikan apakah pendekatan HOTS berpengaruh terhadap keterampilan membaca siswa maka dilakukan uji statistik dari kedua hasil prates dan pascates meliputi uji normalitas, uji homogenitas, dan uji hipotesis. Hasil pengujian tersebut sebagai berikut.

\section{Hasil Uji Normalitas Data}

Uji normalitas dilakukan sebelum menguji hipotesis, hal ini termasuk uji prasyarat yang perlu ditempuh. Maka setelah melakukan uji ini akan memudahkan peneliti dalam menentukan jenis statistik parametrik atau nonparametrik yang akan dilakukan ketika uji hipotesis. Syarat data dapat dikatakan memiliki distribusi normal apabila taraf signifikan lebih dari $>0.05$. Berikut hasil uji normalitas prates dan pascates dapat dilihat pada tabel bawah ini. 
Tabel 1.2

Hasil Uji Normalitas Prates dan Pascates

\begin{tabular}{ccc}
\hline Data & Sig. Kolmogorov-Smirnov & Keterangan \\
\hline Prates & 0.000 & $0.000<0.05=$ tidak normal \\
\hline Pascates & 0.001 & $0.001<0.05=$ tidak normal \\
\hline
\end{tabular}

\section{Hasil Uji Homogenitas Data}

Tujuan dari uji homogenitas ini peneliti dapat melihat data sampel yang asalnya dari populasi yang bervarians berbeda atau sama. Data yang diuji adalah hasil prates dan pascates. Hasil pengujian dapat dikatakan homogen apabila signifikannya lebih besar dari > 0.05. Berikut hasil uji homogenitas nilai prates dan pascates dapat dilihat pada tabel bawah ini.

Tabel 1.3

Hasil Uji Homogenitas Data Prates dan Pascates

\begin{tabular}{ccc}
\hline Data & Signifikansi & Keterangan \\
\hline Prates dan Pascates & 0.807 & $0.807>0.05=$ homogeny \\
\hline
\end{tabular}

\section{Hasil Uji Wilcoxon Sign Rank}

Berdasarkan hasil uji normalitas menyatakan bahwa data hasil penelitian dalam distribusi tidak normal. Maka untuk uji hipotesis yang digunakan penleiti yaitu uji Wilcoxon Sign-Rank. Berikut tabel uji hipotesis hasil prates dan pascates dapat dilihat di bawah ini.

\section{Tabel 1.4}

Hasil Uji Wilcoxon Sign Rank

Test Statistics ${ }^{b}$

\section{Nilai Pascates - Nilai Prates}

\begin{tabular}{lr}
\hline Z & $-5.127^{\mathrm{a}}$ \\
\hline Asymp. Sig. (2-tailed) & .000 \\
\hline
\end{tabular}

Berdasarkan tabel tersebut dapat disimpulkan bahwa uji hasil analisis statistik inferensial nonparametric uji Wilcoxon sign rank diperoleh nilai signifikan lebih kecil dari < 0.05.Maka dapat disimpulkan uji hipotesis dalam penelitian ini sebagai berikut. $\mathrm{H}_{0}$ : Menggunakan pendekatan Higher Order Thinking Skill (HOTS) terhadap keterampilan membaca siswa tidak mengalami perubahan, ditolak. 
$\mathrm{H}_{1}$ : Menggunakan pendekatan Higher Order Thinking Skill (HOTS) terhadap keterampilan membaca siswa mengalami perubahan, diterima.

\section{Hasil Perhitungan Uji-t}

Selain menggunakan pengujian menggunakan aplikasi spss. Peneliti melakukan pengujian secara manual dengan pengujian Uji-t. dengan tujuan memperkuat penelitian yang dilakukan terjadi pengaruh secara signifikan. Arikunto (2013: 310) menyatakan jika harga $t_{\text {hitung }}$ lebih besar daripada tabel hasil tersebut dikatakan signifikan. Berdasarkan hasil perhitungan, bahwa hasil prates dan pascates berbeda setelah diberikan stimulus. Hal ini dikatakan signifikan apabila harga $t_{\text {hitung }}>t_{\text {tabel. }}$. Berikut hasil Uji-t dilihat pada tabel di bawah ini.

Tabel 1.5

Hasil Uji-t Prates dan Pascates

\begin{tabular}{ccc}
\hline $\mathbf{t}_{\text {hitung }}$ & $\mathbf{t}_{\text {tabel }}$ & Keterangan \\
\hline 13.69 & 2.042 & $13.69>2.042=$ Signifikan \\
\hline
\end{tabular}

\section{Proses Pelaksanaan Pendekatan Higher Order Thinking Skill (HOTS) Terhadap Keterampilan Membaca}

Pertemuan pertama peneliti melakukan prates pada siswa dengan membagikan instrumen soal HOTS berbentuk pilihan ganda dan alasan dengan jumlah 20 butir soal. Kegiatan awal pembelajaran melakukan apersepsi. Penelitian pertama ini tidak dilakukan seperti pembelajaran melainkan siswa memanfaatkan waktu tanpa membaca buku dan belajar terlebih dahulu. Siswa diberikan soal HOTS dengan kemampuan awalnya tanpa diberikan stimulus apapun. Hal ini menguji kemampuan siswa dalam menyelesaikan soal yang memiliki tingkatan kognitif yang tinggi. Mengukur kemampuan siswa seberapa jauh siswa mampu menjawab soal beserta alasan yang tepat sesuai dengan pilihan jawabannya. Dari pengukuran ini akan terlihat bahwa siswa sudah memiliki kemampuan berpikir tingkat tinggi atau masih dalam taraf biasa saja.

Pertemuan kedua, penelitian ini dilakukan dengan kegiatan stimulus pada siswa. Stimulus ini dilakukan dengan pembelajaran dalam kelas dan materi yang dipelajari yaitu teks laporan hasil observasi. Pembelajaran ini menggunakan pendekatan Higher Order Thinking Skill (HOTS), siswa terlatih dalam pembelajaran menyelesaikan 
masalah. Kegiatan pembelajaran diawali membacakan doa, memeriksa kehadiran, mengisi agenda kelas, pemberian motivasi, penyampaian kompetensi inti, kompetensi dasar, indikator, dan KKM. Serta literasi berbentuk membaca buku fiksi selama 15 menit. Langkah pembelajaran pertama, siswa diberi stimulus agar memusatkan perhatiannya pada materi yang akan dipelajari dengan cara mengamati, menulis resume, dan menyimak. Stimulus ini peneliti memberikan sebuah materi mengenai isi dan aspek kebahasaan teks laporan hasil observasi agar siswa dapat membaca dan memahami. Setelah paham mengenai isi dan aspek kebahasaannya secara komprehensif, peniliti mengajak siswa agar mencermati dan mengkritisi permasalahan sekitar dan peneliti mengarahkan siswa menemukan satu masalah yang disesuaikan dengan jurusan kelasnya. Kemudian membentuk kelompok untuk menyelesaikan masalah yang berbeda-beda, dalam kegiatan ini terdapat aspek berpikir kritis (critical thinking), kerativitas (creativity), dan kolaborasi (collaborative).

Setelah itu masing-masing siswa mengumpulkan data dan memulai membuat teks hasil laporan observasi minimal 5 paragraf dan menyusun di dalam kelompoknya. Setiap kelompok memiliki 5 teks hasil laporan observasi, dalam kegiatan ini terdapat aspek komunikasi (communication), kolaborasi (collaborative), literasi, dan kreativitas (creativity). Kemudian setiap kelompok diberi waktu untuk membaca hasil karya teman sekelompoknya masing-masing dan mulai untuk menganalisis isi dan aspek kebahasaan hasil teks laporan hasil observasi temannya. Setelah membaca dan menganalisis, siswa diberi kesempatan untuk merevisi dan menarik kesimpulan dari hasil analisis temannya, dalam kegiatan ini terdapat aspek berpikir kritis (critical thinking), dan kreativitas (creativity). Dari penelitian tersebut peneliti dapat menilai hasil analisis presentasi setiap kelompok.

Selanjutnya peneliti meminta setiap kelompok untuk mempresentasikan hasil analisis teks laporan hasil observasi sesuai dengan isi dan aspek kebahasaan. Setelah presentasi selesai setiap kelompok menyampaikan simpulan dari hasil analisisnya. Dalam kegiatan ini terdapat aspek komunikasi (communication), kreativitas (creativity), kolaborasi (collaborative), dan berpikir kritis (critical thinking). Di akhir pembelajaran peneliti menarik kesimpulan pembelajaran yang telah dilakukan dan 
melakukan tanya jawab mengenai ulasan materi teks laporan hasil observasi dan mengakhiri pembelajaran dengan membacakan doa.

Pertemuan ketiga, terakhir peneliti melakukan pascates pada siswa diberi soal HOTS yang sama dengan pertemuan pertama. Hal ini bertujuan untuk mengukur daya berpikir kritis dalam menganalisis soal yang telah dilatih saat dilakukan stimulus pada siswa pada pertemuan kedua. Pascates ini dilakukan lebih maksimal oleh siswa dalam meneliti dan menganalisis soal HOTS dengan membaca pertanyaan yang panjang dan menambah isi kolom alasan dengan tepat. Setelah kegiatan pascates selesai, peneliti memberikan motivasi dan menarik simpulan dari penelitian yang telah dilakukan serta mengakhiri penelitian ini dengan membaca doa.

\section{Deskripsi Pendekatan Higher Order Thinking Skill (HOTS) terhadap Keterampilan Membaca Siswa}

Selama kegiatan belajar mengajar berlangsung, siswa saat menggunakan pendekatan HOTS terlihat lebih antusias dalam berpikir serta menganalisis. Selain itu, siswa mampu menangkap ide atau gagasan dalam suatu bacaan dengan tepat. Hal ini terdapat keterampilan membaca yang menjadi stimulus untuk siswa agar mampu menganalisis, berpikir kritis, berkolaborasi, dan berkomunikasi. Pendekatan HOTS dapat dikatakan lebih efektif dalam menciptakan pembelajaran yang kondusif. Siswa tidak akan menyerah apabila belum menyelesaikan masalah pembelajarannya. Hal ini menuntut siswa menghasilkan produk dari pembelajaran.

Berdasarkan analisis deskriptif yang dilakukan, bahwa hasil prates berada pada kategori kurang sedangkan pascates berkategori baik dengan nilai rata-rata prates 56.17 dan pascates 72.06. Dari hasil analysis data tersebut bahwa hasil belajar pascates setelah diberikan stimulus pendekatan HOTS lebih baik daripada prates sebelum diberi stimulus. Penerapan pendekatan HOTS memberikan dampak positif bagi pembelajaran bahasa Indonesia khususnya pada keterampilan membaca. Siswa menjadi lebih aktif dalam berpikir kritis dan kreatif. Pembelajaran membaca sepanjang apapun kalimatnya akan lebih mudah terselesaikan dengan menggunakan pendekatan HOTS. Kegiatan setelah memberikan stimulus mengalami peningkatan sehingga dapat memengaruhi keterampilan membaca siswa kelas X Jasa Boga I SMKN 3 Kota Sukabumi. 


\section{Pengaruh Pendekatan Higher Order Thinking Skill (HOTS) Terhadap Keterampilan Membaca}

Berdasarkan data hasil penelitian, pengolahan data yang telah dilakukan menyatakan pembelajaran dengan menggunakan pendekatan HOTS berpengaruh signifikan terhadap keterampilan membaca siswa. Hal ini karena adanya pemberian stimulus menggunakan pendekatan HOTS setelah prates. Sehingga siswa mampu belajar secara analitis terhadap materi yang didapatnya dan mampu secara aktif mendorong rasa kaeingintahuannya terhadap permasalahan yang ada serta menyelesaikan masalahnya tersebut. Maka pernyataan ini sesuai seperti yang diungkapkan Wardana (2010) kemampuan berpikir tingkat tinggi yakni tentang sebuah cara untuk berpikir yang meliputi aktivitas mental dalam upaya mempelajari suatu pengalaman yang sulit, reflektif, dan kreatif untuk tercapainya tujuan dengan menghasilkan suatu kompetensi yang dimiliki di antaranya analisis, sintesis, dan evaluasi dan diartikan pula berpikir tingkat tinggi yang merupakan berpikir pada ranah tertinggi tidak mengandalkan kemampuan menghafal pada kenyataan atau sesuatu hal yang perlu identik sama disampaikan kembali apa yang telah dikatakan. Dengan pernyataan ini, terbukti bahwa pembelajaran menggunakan pendekatan HOTS salah satunya dapat menambah keterampilan membaca siswa.

Selanjutnya ditinjau dari hasil pascates setelah mendapatkan stimulus menggunakan menggunakan pendekatan HOTS terdapat nilai yang signifikan berada di bawah 0.05 yaitu sebesar 0.000 . Hal ini dapat diketahui terdapat perbedaan yang signifikan dari setelah pemberian stimulus. Maka dapat disimpulkan bahwa terdapat pengaruh penggunaan pendekatan HOTS terhadap keterampilan membaca siswa kelas X Jasa Boga I SMKN 3 Kota Sukabumi.

\section{Data Lembar Observasi Pembelajaran dengan Menggunakan Pendekatan HOTS}

Data lembar observasi merupakan salah satu Ttknik pengumpulan data yang digunakan peneliti untuk mengetahui bagaimana respon siswa terhadap pembelajaran menggunakan pendekatan HOTS. Lembar observasi diisi oleh observer yakni guru bahasa Indonesia kelas X SMKN 3 Kota Sukabumi. Kemudian lembar observasi 
sikap displin siswa bertujuan untuk mengetahui tingkat kemampuan HOTS terhadap kedisplinan siswa (Pratiwi dan Eka Farida, 2015).

Berdasarkan hasil observasi, siswa mengikuti langkah-langkah pembelajaran dengan baik sesuai yang telah diarahkan peneliti. Selain dari itu, hasil dari pengamatan peneliti dapat melakukan prosedur yang telah disusun sehingga dapat menarik minat belajar siswa dalam berpikir tingkat tinggi. Kemudian dari hasil pengamatan menyatakan bahwa siswa mampu belajar berpikir analisis, kreatif dan kritis. Hal ini dapat dilihat dari kegiatan siswa dalam pembelajaran yang telah dilakukan.

Hasil analisis pengaruh pendekatan HOTS terhadap sikap kedisiplinan siswa dilihat dari keaktifan siswa dalam melaksanakan pembelajaran di kelas. Sehingga hal ini meningkatkan keterampilan membaca siswa dalam mencapai kemampuan berpikir tingkat tinggi.

\section{PENUTUP}

Berdasarkan data hasil penelitian menyatakan bahwa pendekatan Higher Order Thinking Skill (HOTS) berpengaruh terhadap keterampilan membaca siswa. Hasil dari uji Wilcoxon sign rank menunjukkan bahwa data yang diperoleh dinyatakan signifikan yakni $0.000<0.05$, maka $\mathrm{H}_{0}$ ditolak dan $\mathrm{H}_{1}$ diterima. Kemudian dari hasil uji-t menghasilkan data yang sesuai dengan kriteria dengan $t_{\text {tabel }}=13.69>t_{\text {hitung }}=$ 2.042 dengan tingkat kepercayaan 0.05. Dari data tersebut dapat diketahui bahwa pendekatan HOTS berpengaruh terhadap keterampilan membaca siswa, hal tersebut dapat dilihat dari distribusi nilai prates dan pascates mengalami peningkatan. Adapun hasil observasi siswa terhadap penerapan pendekatan HOTS secara keseluruhan menunjukkan kesesuaian siswa dalam melakukan langkah-langkah pemeblajaran HOTS. Sehingga terlihat respon siswa sangat baik dalam pembelajaran menggunakan pendekatan HOTS.

Dari hasil penelitian dapat diketahui bahwa pembelajaran dengan menggunakan pendekatan HOTS memberikan pengaruh positif terhadap keterampilan membaca siswa sehingga menghasilkan pengaruh yang signifikan. 


\section{DAFTAR RUJUKAN}

Arikunto, S. 2013. Prosedur Penelitian Suatu Pendekatan Praktik. Jakarta: Rineka Cipta.

Dalman. 2013. Keterampilan Membaca. Jakarta: Gaya Grafindo Persada.

Hanifah, Nurdinah, dan Julia. 2014. Prosiding : Seminar Nasional Pendidikan Dasar "Membedah Anatomi Kurikulum 2013 untuk Membangun Masa Depan Pendidikan yang Lebih Baik. Bandung: UPI Sumedang Press.

Heong, Y. M. et. al. 2001. The Level of Marzano Higher Order Thinking Skill Among Technical Education Student. Dalam International Jurnal of Social and Humanity [Online], Vol 1 (2), 5 halaman. (https://www.researchgate.net/publication/255720579_The_Level_of_Marzano _Higher_Order_Thinking_Skills_among_Technical_Education_Student, diunduh 05 Desember 2018).

Julia, Isrok'atun, dan Indra Safari. 2018. PROSIDING SEMINAR NASIONAL: Membangun Genarasi Emas 2045 yang Berkarakter dan Melek IT" dan Pelatihan "Berpikir Suprarasional”. Bandung: UPI Sumedang Press.

Maulana. 2018. DASAR-DASAR KONSEP PELUANG: Sebuah Gagasan Pembelajaran dengan Pendekatan Metakognitif. Bandung: UPI PRESS.

Meliyawati. 2016. Pemahaman Dasar Membaca. Yogyakarta: Deepublish.

Pratiwi, Umi dan Eka Farida Fasha. Pengembangan Instrumen Penilaian HOTS Berbasis Kurikulum 2013 Terhadap Sikap Displin. Dalam Jurnal Penelitian dan Pembelajaran IPA [Online]. Vol 1 (1), 20 halaman. (http//jurnal.untirta.ac.id/index.php/JPPI/article/view/330/230, diunduh 10 Desember 2018).

Purnamasari. 2015. Peningkatan Keterampilan Membaca Siswa Kelas II Melalui Metode Cooperative Script Pada Mata Pelajaran Bahasa Indonesia Di SDN Perwira V Bekasi Utara. Skripsi: tidak diterbitkan.

Wardana, N. 2010. Pengaruh Model Pembelajaran Berbasis Masalah dan Ketahanmalangan terhadap Kemampuan Berpikir Tingkat Tinggi dan Konsep Fisika. Jurnal Ilmiah Pendidikan dan Pembelajaran [Online], Vol 6 (2), 20 halaman. Tersedia: (http://oldpasca.undiksha.ac.id/e-journal/index.php/jurnal, diunduh: 05 Desember 2018). 